IRA-International Journal of Education \& Multidisciplinary Studies

ISSN 2455-2526; Vol.04, Issue 02 (2016)

Pg. no. 226-236

Institute of Research Advances

http://research-advances.org/index.php/IJEMS

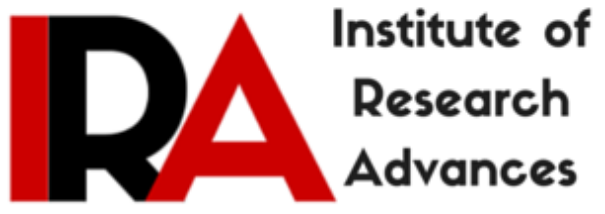

\title{
A Thing-Oriented Perspective of Ancient Indian Philosophy
}

\author{
M. John Britto \\ Assistant Professor of English \\ St. Joseph's College (Autonomous) \\ Tiruchirappalli-620002 \\ Tamil Nadu, India.
}

Type of Review: Peer Reviewed

DOI: http://dx.doi.org/10.21013/jems.v4.n2.p1

\section{How to cite this paper:}

Britto, M. (2016). A Thing-Oriented Perspective of Ancient Indian Philosophy. IRA International Journal of Education and Multidisciplinary Studies (ISSN 2455-2526), 4(2), 226-236. doi:http://dx.doi.org/10.21013/jems.v4.n2.p1

(C) Institute of Research Advances

\section{(cc) BY-NC}

This work is licensed under a Creative Commons Attribution-Non Commercial 4.0 International License subject to proper citation to the publication source of the work.

Disclaimer: The scholarly papers as reviewed and published by the Institute of Research Advances (IRA) are the views and opinions of their respective authors and are not the views or opinions of the IRA. The IRA disclaims of any harm or loss caused due to the published content to any party. 


\section{ABSTRACT}

With the emergence of thing-oriented doctrines in the recent times, there is a gradual shift of attention from human subjects to material objects in the contemporary educational realm. Thing theory and objectoriented ontology, as thing-oriented doctrines, are in equilibrium with their primary concern with things. Both of them are pertinent to each other in multifarious ways. While thing theory is concerned with the significance of things in relation to literature and culture, object-oriented ontology focuses on the centrality of things in philosophy. The study made by thing-oriented scholars divulges that the worth of corporeal things has been overlooked by humans down the ages. However, there are a few instances here and there wherein things were said to gain some attention. This research paper seeks to make a study of how things were understood in the schools of ancient Indian philosophy, and it looks at the views of those schools on things from a thing-oriented perspective. It explores the general philosophy of the Upanishads concerning the reality of things in the world. It also attempts to identify and elucidate the constructive views on things which could be traced in the doctrines of the philosophical schools of the Nyaya, the Vaisheshika, the Sāmkhya, the Mìmāmsa and the Cārvāka. These schools' realist approach to things is contrasted with the monistic idealism of the schools of the Advaita Vedanta and the Yoga. The paper also examines how things are undermined and overmined in ancient Indian philosophy.

Key Words: thing theory, object-oriented ontology, Indian philosophy, dravya, prameya, padārthas, māhabhūtas, satkāryavāda, pariṇāmavāda, undermining, overmining.

\section{INTRODUCTION}

The different schools of ancient Indian philosophy have documented diverse views on things. They upheld certain ideas which were object-oriented and which could be looked at from the viewpoint of thing theory and object-oriented ontology. Rudiments of optimistic views on things can be principally traced in the form of realism propounded by the teachings of the schools like the Nyāya, the Vaisheshika, the Sāṃkhya, the Mīmāṃsā and the Cārvāka. In this regard, a brief account of the ancient Indian philosophical schools would enlighten us more to comprehend the views on things in Indian context, as recorded in Indian philosophy.

As documented by Jadunath Sinha in his Outlines of Indian Philosophy (1985), in India, "Philosophy is called Darśana, which means vision. Philosophy is the vision of the Reality as a whole. It is an insight into the nature of the whole reality" (1). Indian philosophy, in its essence, is spiritual. The ancient Indian philosophical schools or systems fall under two categories - orthodox (āstika) and heterodox (nāstika). Those which do not accept the authority of the Vedas are called heterodox or non-orthodox schools. They are Buddhism, Jainism and the Cārvāka. Those schools that believe in the authority of the Vedas are known as orthodox schools. There are six systems (darshans) of Indian philosophy that admit the authority of the Vedas. They are the Nyāya, the Vaisheshika, the Sāṃkhya, the Yoga, the Mīmāṃsā, and the Vedānta. Of them, the Nyāya, the Vaisheshika, the Yoga and the Vedānta are theists, while the schools such as the Sāṃkhya and the Mīmāṃsā are atheists (1-2). Furthermore, realism, which is associated with things, thing theory and object-oriented ontology, was campaigned by the Nyāya, the Vaisheshika, the Sāṃhya, the Mīmāṃsā and the Cārvāka. The idealist notions were taught by the Vedānta and the Yoga.

\section{THE GENERAL PHILOSOPHY OF THE UPANISHADS CONCERNING THINGS}

The doctrines of the orthodox schools of ancient Indian philosophy are rooted in the Upanishads, which are parts of the Vedas. There are four Vedas namely the Rig Veda, Yajur Veda, Sāma Veda and Atharva 
Veda, of which the first three are considered the original Vedas, and the last one is believed to be a later addition. Each Veda is divided into three types: (i) the Samhitās which are mostly verses, (ii) the Brāhmaṇas which are commentaries in prose, and (iii) the Āranyakas, which are forest treatises. The Upanishads form mostly a part of the Āranyakas. Different types of religious thought like polytheism, organized polytheism, henotheism, monotheism and monism are found in the Vedas. The grand, sublime, beautiful and useful aspects of nature were often personified and deified as supernatural entities, and they were worshiped as deities that were believed to preside over the diverse phenomena of nature. Sometimes, the natural things and different powers of nature were personified and worshiped as gods. For example, the Vedas talk about the gods of fire (Agni), the sun (Sūrya), the dawn (Ūṣa), the earth (Pṛthivī), the sky (Dyaus), the bright sky and day (Mitra), the dark sky and evening (Varuna), the raincloud (Parjanya), the storms (Maruts), the winds (Vāyu, Vāta), the morning sun (Savitṛ) and so on (Sinha 18-19).

Thus, we find that people during the Vedic period offered a central place to the powerful things of nature and went to the extent of deifying them and worshiping them. In the sense of paying attention to things in nature, a thing-oriented approach to the Vedic thought is very optimistic. However, seen from the central claims of object-oriented ontology, which seeks to put "the objects at the centre of being" (Braddock 459, Bogost 6), and which insists on the equality and autonomy of all things in the sense of their being, all things are not treated equally in the Vedic thought. That is, the personification and deification of powerful things in nature indicate their superiority over all other things including human being. It is also found that as people leaped gradually from polytheism to monotheism, the number of personified and deified things of nature got decreased, culminating ultimately in the worship of a single god.

Polytheism refers to personification of the different powers of nature and worshipping them as gods that are supernatural and superhuman powers endowed with spiritual qualities. Organized polytheism refers to the phase of religion wherein " $[\mathrm{t}]$ he gods are gradually related to one another as the major and the minor, as dependent on one another, and as generating one another" (Sinha 19). For example, Heaven and Earth are regarded as the mothers of Agni, Rudra as the father of Maruts, Aditi as the mother of the Adityas, and the Aśvins as the brothers. Indra maintains the Earth and the Sky, and is regarded as a major god and others as minor deities. The next phase of religion was henotheism in which one god, among many gods, was treated as the supreme god at the time of worshipping him (19). Thus, the hierarchy began to grow among the deified things of nature. In this sense, even among the powerful things of nature, there is a sense of superiority and inferiority which is an anti-object-oriented feature. The hierarchy of things in terms of their superiority undermines the things which are considered lower or inferior.

The concept of Rta becomes the harmonizing agent of different gods, paving the way for monotheism. Rta is the physical and natural order which reigns everywhere. Gradually, Hiranyagarbha or Prajāpati (the lord of all creatures), Viśvakarmā (the creator of the universe), and Parama Purusha (who is transcendent and immanent in the whole world) occupy the place of one supreme God who is considered the creator of the universe and all things in the world. Finally, there is a leap from monotheism to monism wherein one Reality is conceived and believed to be manifested in different ways (20-21). Here, the fundamental reality of the individual objects with their autonomy promulgated by object-oriented ontology is denied to the objects which are regarded as false appearances.

In general, the Upanishads accepts that the world and all objects in it are real, and in this sense, the things in the world attain some recognition. It insists on the doctrine of emanation, claiming that "[a]1l creatures come out from the Atman or Brahman, as sparks come out from fire, as plants shoot forth on the earth, as hairs spring from a living body, or as threads come out from the body of a spider" (41). The creatures, here, signify all corporeal things or objects in the world. Furthermore, Prakriti is considered to be "the conscious power of God, which can create the multiform world of various objects" (43). At the outset, it should be noted that "[e]very system of Indian philosophy admits the reality of the world, at least as an 
appearance, accounts for its variety and multiplicity, and provides for the realization of our practical needs" (Sinha 9-10). However, the range of importance given to the material things and the world varies from school to school.

\section{THE NOTION AND PLACE OF THINGS IN THE ANCIENT INDIAN PHILOSOPHICAL SCHOOLS}

\subsection{The Orthodox Schools of Philosophy}

As noted earlier, in ancient Indian philosophy, the schools that admit the authority of the Vedas are called orthodox schools. They are the Nyāya, the Vaisheshika, the Mīmāṃsā, the Sāṃkhya, the Vedānta and the Yoga.

\subsubsection{The Views of the Nyāya Concerning Things}

The Nyāya system, which is said to have been founded by Gautama or Akṣapāda, deals primarily with epistemology and logic, and secondarily with ontology. It seeks to explain not only the sources of knowledge, but also the conditions of their validity, and the nature of the world, souls and god (Sinha 205). Thing theory and object-oriented ontology highlight the centrality of material things in the world.

\subsubsection{Significance of Nyāya Epistemology in Relation to Things}

Nyāya epistemology and its doctrine of the world disclose the traces of views which are thing-oriented and which insist on the significance of things to some extent. Knowledge necessarily involves knowledge of things in the world. In this context, the Nyāya epistemology documents certain views on things. It believes that "[k]nowledge is the manifestation or apprehension of objects. Valid knowledge is the apprehension of the real character of an object" (Sinha 207). It claims that the reality is constituted by the knower, the thing that is known, the instrument of knowledge, and valid knowledge. Here, the self is the knower, prameya is the object that is known, and pramanna is the instrument by which the self knows the things or objects in the world. The self knows the things in the world through four pramannas (sources of knowledge) namely perception, inference, comparison and testimony, acts upon the objects, and experiences the fruits of its actions. The Nyāya believes in the self and the thing or object as necessary factors for any valid knowledge, and considers them the common causes of knowledge of things in the world (205-206). Put differently, a knower cannot know anything without things in the outer world. Within the purview of thing theory and object-oriented ontology, the Nyāya's insistence on the indispensability of things in the outer world for having valid knowledge is very much a thing-oriented feature.

\subsubsection{Realist Approach to Things}

Realism is a relevant factor of thing-oriented doctrines like thing theory and object-oriented ontology which are mutually linked. In philosophy, realism refers to "any viewpoint that accords to objects of human knowledge an existence that is independent of whether they are being perceived or thought about" (Britannica Ready Reference Encyclopedia, VIII, 131). Put simply, realism admits an independent existence of things in the world outside the human mind. Idealism, on the other hand, denies this claim of realism, and affirms that things exist only in the human mind. Therefore, thing-oriented doctrines denounce the position of idealism. The Nyāya doctrine of valid knowledge divulges its realist approach to things:

Valid knowledge is the knowledge that represents the real character of its object, or apprehends what exists in it. Error is the knowledge that does not represent the real character of its object, or 
apprehends what does not exist in it. So the knowledge which corresponds with the real nature of its object is valid, and the knowledge which does not correspond with its real character is invalid. (Sinha 206)

The realist approach to things, campaigned by the Nyāya, is in fact parallel to the Western realism. Object-oriented ontology, as pointed out by Levi R. Bryant, who calls his own object-oriented philosophy "onticology", holds firmly that this universe is entirely made up of individual objects: "all being is composed of objects" (as quoted in The Meillassoux Dictionary, n.p.). Similar thought is reflected in the declaration of the Nyāya that valid knowledge necessarily involves the existence of independent things in the outer world.

\subsubsection{Vaisheshika's Stand Concerning Things}

The central philosophy of the Vaisheshika (or Vaiśeșika) system, which was founded by Kạāa (300 B.C.), is the doctrine of atomism, according to which, "all objects in the physical universe are reducible to a finite number of atoms" ("Vaisheshika Darshana" n.p.) of the four great elements such as earth, water, fire and air. The Nyāya and the Cārvāka schools of philosophy also admit the atomic theory, insisting on these four elements as the basic elements of all objects in the universe. The Nyayya and the Vaisheshika share many factors in common. Therefore, they are, at times, known as the Nyāya-Vaisheshika school. Both of them admit the reality of God, plurality of individual souls, and the world of multiple objects. They both admit the reality of the world in time and space.

\subsubsection{Padārthas (Objects of Experience)}

The word, Vaiśeșika, comes from the Sanskrit term, viśeșa, which means particularity or individuality or " "uniqueness' - the characteristics that distinguish a particular thing from all other things" (Sturgess 77). The Vaisheshika's thing-related ideas are found in its account of atomism, and of dravya (substance), which is one of the padārthas. Padārthas (objects of experience) refer to "all things which exist, which can be cognised, and which can be named" ("Vaisheshika Darshana" n.p.). The Vaisheshika school divides all things in the universe into six categories of the padārthas or objects of experience: they are dravya (substance), guṇa (quality), karma (activity), sāmānya (generality), viśeșa (particularity) and samavāya (inherence). The category, abhāva (non-existence), was added later.

\subsubsection{The Atomic Theory of Vaisheshika: Four Māhabhütas as the Constituents of All Things}

Sāmānya (generality) refers to a common property found in several things. In spite of certain common properties, each thing has its own unique features and thus differs from other things in the world. It is the viśeșa (uniqueness) which enables us to distinguish each thing from all other things. The Vaisheshika school believes in nine dravyas (substances), which are pṛthvī (earth), ap (water), tejas (fire), vāyu (air), ākaśa (sky or ether), kāla (time), dik (space), ātman (self) and manas (mind) (Ibid). As noted by Sturgess, "[t]he first five dravyas (earth, water, fire, air and ether) are called mähabhütas, substances that have specific qualities that can be perceived by the senses" (77). The Vaisheshika believes that the atoms (paramānus) of the four elements (māhabhütas) namely earth, water, fire and air are eternal, indivisible and the minutest units of substances, and they can be neither created nor destroyed. However, they can get fused into composite substances that can be produced and destroyed. While qualities of atoms are eternal, those of the composite substances are not eternal (Sinha 178-179). Ether, the fifth māhabhūta, which is also eternal and all-pervasive, does not have atoms. The atomic theory of the Vaisheshika can be compared to that of the pre-Socratic philosopher Empedocles, who, as stated by Frederick Copleston, believed that all things in the world are composed of four ultimate elements namely water, air, fire and earth under the action of love and strife (76-78). It reveals that all things in the universe contain certain 
number of atoms of the four māhabhūtas namely earth, water, fire and air. The number of atoms of each element in a thing may differ from one another.

\subsubsection{Thing-Oriented Relevance}

The Vaisheshika's atomic theory discussed above reminds us of the object-oriented ontologist Ian Bogost's view in relation to flat ontology: "all things equally exist, yet they do not exist equally" (11). That is, flat ontology, as defined by Bogost, affirms that "things can be many and various, specific and concrete, while their being remains identical" (12). The claim of object-oriented ontology that all things are equal becomes relevant to the theory of atomism in the sense that all things contain the atoms of the earth, water, fire and air. At the same time, as Graham Harman, a leading object-oriented philosopher, argues, the atomic theory reduces the fundamental reality of all things to the four great elements such as earth, water, fire and air. He calls such attitude of reductionism the "undermining" of things (8-10). Put differently, undermining of things, according to Harman, refers to the reductionist attitude of those strategies which "view objects as too shallow to be the fundamental reality in the universe" (10). The undermining theories treat objects as "simply superficial crusts to a deeper underlying reality" (Harryman n.p.). In this sense, the idea of the Nyāya, the Vaisheshika and the Cārvāka schools of philosophy that all things are composed of the atoms of the four māhabhūtas (earth, water, fire and air), seems to undermine the independent individual things in the world, by reducing their fundamental reality to those four māhabhūtas.

\subsubsection{Views of the Mīmāmsā on Things}

The atheistic school, Mīmāṃsā, was founded by Jaimini (400 B.C.), and it is also known as Pūrva Mīmāṃsā. The word mìmāms ā is a Sanskrit term which signifies "revered thought". In the context of the Indian philosophical systems, it refers to "probing and acquiring knowledge' or "critical review and investigation of the Vedas"" ("Purva Mimamsa" n.p.). Pūrva means "earlier". Since Mīmāṃsā deals with the earlier parts of the Vedas, it is also called Pūrva Mīmāmsā. Vedanta, on the other hand, is called Uttara Mīmāṃsā. Uttara means "later". Uttara Mīmāṃsā focuses on the later parts of the Vedas. Pūrva Mīmāṃā is centred on ritualism. As mentioned by Sinha, Pūrva Mīmāṃsā denies God as the creator of the world. However, it accepts the reality of the individual selves and the self-existent material world (2). In other words, it is a pluralistic and realistic philosophy which believes that the world and all things in it are real. It regards the world as an eternal and uncreated entity governed by the laws of Karma (Dwarakanath n.p.). The doctrine of Mīmāmsā reveals that it admits the reality of individual things that exist in the world. Its belief in a pluralistic world and its acceptance of the reality of the world and all things therein exhibit the fact that the Mīmāmssā school of philosophy had paid some attention to things.

\subsubsection{The Sāmkhya Approach to Things}

Realism is an essential concept which is espoused by thing theory and object-oriented ontology. Rudiments of realism are perceivable in the Sämkhya school, founded by the sage Kapila. The term, Sāmkhya, is derived the Sanskrit word, samkhya, which means "number". Sāṃkhya also means "perfect knowledge". In this sense, it is a system of perfect knowledge. This school attempts to impart knowledge of reality by specifying the number and nature of the ultimate constituents of the universe. The Sāmkhya has a realist approach to things. It rejects the belief of the Nyaya-Vaisheshika and Jainism that atoms are the ultimate constituents of the physical world. It argues that atoms of matter cannot be the cause of subtle and fine objects like mind and intellect, and therefore, there should be some finest and subtlest matter, which underlies all physical existence. The Sāmphya calls such matter "Prakriti". In fact, it believes in two ultimate realities namely Prakriti (matter) and Purusha (self/spirit), and affirms that both are equally real and eternal (“Samkhya” n.p.). 


\subsubsection{Satkāryavāda: Preference to Prakriti-Parin̄āmavāda}

The Sāṃkhya notion of Prakriti is rooted in Satkāryavāda ("theory of causality"), which holds that "the effect (kārya) is existent (sat) in the cause prior to its production" (Gupta n.p.). Satkāryavāda states that changes in the world and things therein are "caused" and are not mere "chance occurrences" (Ibid). It also contends that:

Nothing new ever comes into being, only a new form is manifested; the matter remains the same. As yogurt is produced from milk, or oil from the oil-seeds, or jewelry from a lump of gold, a new form is imparted to the preexistent stuff. This variety of satkäryaväda, i.e. the theory that effect is a real transformation of the cause, is known as parināmavāda (literally, 'real-transformationstatement'). (Ibid)

Two different interpretations are ascribed to the concept of Satkāryavāda: Prakriti-parināmavāda and Brahma-vivartavāda. Parināmavāda is the theory of transformation which holds that "the effect is the real parinama (or transformation) of the cause" ("Samkhya" n.p.). The Sanskrit word, vivarta, means "apparent transformation" (Hiriyanna 159). Vivartavāda signifies "the doctrine of false transformation or of apparent change" (159). It is the theory of causation which claims that "transformation is only apparent, as the Brahman is the only true cause and the world is a distorted appearance of the cause" ("Samkhya" n.p.). Sāṃkhya advocates Prakriti-pariṇāmavāda while the Advaita Vedānta defends Brahma-vivartavāda.

\subsubsection{The Sāmkhya as a Dualistic Realism: The Doctrine of Purusha and Prakriti}

The Sāmkhya school is essentially a dualistic realism: It is dualism because of its belief in two ultimate realities such as Prakṛti (or Prakriti) and Purușa (or Purusha), and it is realism because of its claim that matter and spirit are equally real. It also believes in plurality of Purusha, and in this sense, it is pluralistic. It regards Prakriti not only as the primordial substance and material cause of the world, and but also as the first and ultimate cause of all gross and subtle objects. Since Prakriti is the non-self, it is devoid of consciousness. It becomes manifest as objects of experience of Purusha ("Samkhya" n.p.). Purusha is conscious, inactive and immutable. Prakriti, on the contrary, is dynamic and mutable, and is composed of three gunas (qualities) such as satva (beingness), rajas (activity/dynamism) and tamas (darkness). These gunas, which become the very essence of Prakriti, are finer than atoms, and they get modified into all physical, biological and psychical entities. Furthermore, they serve as the constituent elements of both Prakriti, and all objects in the world that are produced by Prakriti (Sinha 2-3).

\subsubsection{A Thing-Oriented Glance}

From thing-oriented perspective, the Sāmkhya's realist position unveils its acceptance of existence of the individual things outside the human mind. Its claim that matter and spirit are equally real is in perfect line with flat ontology of things which asserts "that all objects are equal in so far as they are objects" (Gabriel n.p.). In this way, the Sāmkhya's assertion of equality of matter and spirit is in opposition to the Cartesian dualism of body and soul which, as noted by M. John Britto, privileges human being over other entities because of the former's (human) possession of soul (721). Object-oriented ontology rejects the Cartesian dualism on account of privileging humans over nonhuman things. However, the Sāmkhya's views on Satkāryavāda, particularly on Prakriti-pariṇāmavāda, reveal that the fundamental matter of all material things in the world is Prakriti, and the individual material things are merely different forms of the same matter, Prakriti. Thus, the Sāṃkhya's Prakriti-parināmavāda undermines the individual things, by reducing their fundamental existence to the Moola-Prakriti (Primordial Matter). 


\subsubsection{The Doctrine of the Advaita Vedānta and the Yoga}

Monism and idealism are negative factors of thing-oriented perspective. In Indian philosophy, these factors are primarily found in the teachings of the Advaita Vedānta, a sub-school of the Vedānta, which is also called Uttara Mīmāṃsā. Vedānta means "end of knowledge" or "the final conclusion of the Vedic philosophy". As remarked by Sinha, the Yoga, which too propagates idealism, accepts the dualism of Purusha and Prakriti propounded by the Sāmkhya, but makes it theistic. Therefore, it is sometimes called the theistic Sāṃkhya. It believes that Prakriti is independent of God. But the Sāmkhya rejects the concept of God. The significant feature of the Yoga is its insistence on the practice of the art of yoga to achieve moksha (3). In other words, the Yoga school of philosophy offers the practical methods "to realize the purusha distinct from prakriti" (Dasa n.p.). It denies the production of a non-existent thing and destruction of an existent thing, and promulgates the theory of Satkāryavāda (theory of causality), or Pariṇāmavāda (theory of transformation) (Sinha 294).

\subsubsection{The Advaita Vedānta's Idealist and Absolute Monism: Defending Brahma-Vivartavāda}

The Vedānta is centred on the nature and knowledge of Brahman, and it consists of two major schools such as the Advaita Vedānta founded by Adi Shankara, and Vishishtadvaita Vedānta founded by Ramānuja. The Shankara's Advaita Vedānta advocates idealist and absolute monism (Sinha 4). Ramānuja rejects the absolute monism of Shankara and accepts the reality of the world and the things therein. At the same time, he "regarded the souls and the world as attributes of God" (414), equating Brahman with God (414-415). He too believes in Satkāryavāda. He unveils that "all objects are known through experience" (433). He considers the world "a transformation of prakṛti which is a power of God" (435). Ramānuja's acceptance of the reality of the world and the individual things therein makes his view thing-oriented. However, his belief in the world and all things therein as mere "attributes of God" and as "a transformation of prakrti" seeks to undermine the fundamental reality of things. From the perspective of Graham Harman's object-oriented philosophy, idealism seeks to overmine the material things, while monism attempts to undermine them (13). The Shankara's Advaita Vedānta advocates both idealism and absolute monism. It is an idealist philosophy because it regards the plurality of the individual things as mere appearances or illusion. It is monism because it believes in a single ontological reality. In other words, the Advaita Vedānta, as noted by Sinha, claims that there is only one ontological absolute reality, Brahman, affirming that the world, all empirical things and the individual selves (jīva) are mere appearances or Māya or illusion (4). Thus, the Advaita Vedānta defends Brahma-vivartavāda (the theory that regards Brahman as the true cause and the world as a distorted appearance of the cause).

\subsubsection{The World and Things Therein as Māya}

As stated above, the Advaita Vedānta regards the world and all things therein as Māya (illusion). The concept of Māya, according to Hendrick Vroom, signifies that "the world is not as it seems; the world that one experiences is misleading as far as its true nature is concerned" (as cited in "Maya (illusion)" n.p.). Put in the words of Lynn Foulston, "The world is both real and unreal because it exists but is "not what it appears to be" (as cited in "Maya (illusion)" n.p.). In other words, Brahman, the absolute reality, never undergoes any change while the perceived material objects appear to change. Thus, the true identity of Brahman is forgotten, and the material reality which is perceived in plurality is taken to be the real identity. This aspect becomes clearer in the words of Sangeetha Menon concerning Advaita metaphysics:

Brahman - the ultimate, transcendent and immanent God of the latter Vedas-appears as the world because of its creative energy (māyā). The world has no separate existence apart from Brahman. The experiencing self (jīva) and the transcendental self of the Universe (ātman) are in 
reality identical (both are Brahman), though the individual self seems different as space within a container seems different from space as such. (n.p.)

The principal teaching of the Advaita Vedānta is summarized in a single sentence: "Brahman is alone True, and this world of plurality is an error; the individual self is not different from Brahman", and the experience of plurality is due to "error in judgments (mithya) and ignorance (avidya)" (Ibid). The ultimate liberation is possible by attaining true vidya (knowledge) of Brahman.

\subsubsection{Undermining and Overmining of Things}

Within the framework of thing-oriented doctrines, the absolute monism upheld by the Advaita Vedānta discloses its anti-object-oriented approach to things, because monism, as stated by Harman, is a theory that undermines objects by treating them as mere derivative products of some other fundamental source (10). In fact, Timothy Morton convincingly argues that "[t]he ooo [object-oriented ontology] universe just can't be monistic" (211). For pure monism, "all is one" and "the multiplicity of things encountered by senses is illusory" (Harman 14). The absolute monism promulgated by the Advaita Vedānta insists on a single ontological absolute reality, Brahman (Sinha 4). Thus, it undermines the individual things in the world by reducing their existence to a single ontological reality.

Object-oriented ontologists denounce such undermining position and declare with conviction that individual things are truly real and are autonomous beings. Overmining of things, for Harman, refers to the position of those theories which claim that things or objects "are too deep" (10), and which believe that "objects are important only insofar as they are manifested to the mind, or are part of some concrete event that affects other objects as well" (11). The idealists deny the existence of the world and the objects therein outside the human mind. It is palpable in the famous dictum of George Berkeley, who is generally regarded as the father of modern idealism in Western philosophy: "Esse est percipi", meaning "To be is to be perceived" (as cited in Dicker 3). In other words, the material things are only ideas, and they exist only by being perceived (3). The Advaita Vedānta, with its principle of idealism, overmines the material objects in the world by regarding them as mere appearances or illusion, and by asserting that feeling of plurality of things is due to avidya (ignorance).

\subsection{The Heterodox Schools of Philosophy}

\subsubsection{The Views of Buddhism and Jainism: the Significance of Hīnayāna Buddhism}

As regards non-orthodox schools of Indian philosophy, the traces of thing-related ideas are perceptible particularly in the doctrines of the Hīnayāna Buddhism and the Cārvāka, and therefore, these two schools are important in thing-oriented sense. Buddhism, Jainism and the Cārvāka are the heterodox schools that reject the authority of the Vedas. They are atheists as well. Jainism, as remarked by Sinha, denies the existence of God as the creator of the world, and accepts reality of the world and permanent souls. It regards the world as a material entity and souls as spiritual beings (8-9). There are traces of remarks on external material objects in Buddhism, which is classified into the Mahāyāna and the Hīnayāna. The Hīnayāna Buddhism advocates realism, claiming that "knowledge corresponds to objects outside and independently of knowledge" (Marbaniang 17). This view is parallel to that of the Western realism which is object-oriented and pertinent to thing theory and object-oriented ontology. However, there is a difference of opinion between the two schools of the Hīnayāna: according to the Vaibhāșikas "objects are directly perceived", but for the Sautrāntikas, "objects are known through representations and not directly" (17).

The Mahāyānists are categorized into the Yogācāras and Mādhyamikas. The Yogācāras are subjective idealists who reduce "the external objects to mere ideas of the perceiving mind" (Sinha 9). In this way, 
the Yogācāras overmine the material things. Their view is akin to that of Berkeley's subjective idealism which claims that "there really is nothing outside the human-world coupling" (Harman 65). They believe that "all perception of external objects is false and that all knowledge arises from within" (Marbaniang 17). The Mādhyamikas claim that "no-thing is real", and thus they deny "the ultimate reality of both the internal and the external" (18). They believe that reality is "void (sunya) which is essenceless, predicateless, indefinable and incomprehensible" (Sinha 7). Therefore, their theory is called Sunyavāda ("theory of the void" which is also known as nihilism).

\subsubsection{The Cārvāka School: Emphasis on Materialism and Atomism}

The atheist philosophical school of the Cārvāka propounds materialism. The Cārvākas, as materialists, regard "pratyaksha [direct perception] as the sole means of valid knowledge" (Marbaniang 17). In other words, they believe in "direct perception as the surest method to prove the truth of anything" "Cārvāka" n.p.). The Cārvākas in India are parallel to the Epicureans in the West. Both of them insist on happiness and pleasure, and are materialists. It is held that they also fought against the irrational and superstitious practices in the society and in different religions ("Charvaka and Epicureanism" n.p.). Like the Nyaya and the Vaisheshika schools, and like the pre-Socratic philosopher Empedocles, the Cārvāka school regards the gross elements such as earth, water, fire and air as the constituents of the world. It does not believe in the existence of God or any supersensible entities, and insists on physical pleasure (Sinha 6-7). It also admits the reality of existence of things in the outer world outside the human mind. This is a positive note on things from a thing-oriented perspective. However, its idea of materialism seems to bear the seeds of anti-object-oriented position. According to Graham Harman, materialism is a strategy which undermines and overmines things simultaneously (13). Therefore, he claims that "materialism is the hereditary enemy of object-oriented ontology" (13). In this way, the Cārvāka, because of its insistence on materialism, has some impressions of negative attitude to things. On one hand, its belief that all things consist of the atoms of earth, water, fire and air, could be considered positively, because it seems to disclose the fact that all things are equal in terms of possession of all the four great elements. On the other hand, when the same belief is looked at from the perspective of object-oriented ontology as viewed by Harman, it seems to undermine the individual things in the outer world by reducing their fundamental base to the four great elements.

\section{CONCLUSION}

All the systems of the ancient Indian philosophies admit the existence of things, at least as an appearance. Their views on things disclose both positive and negative approach to things. The traces of optimistic views on things disclosed by the ancient Indian philosophical systems like the Nyāya, the Vaisheshika, the Sāṃkhya, the Mīmāṃsā and the Cārvāka serve as a classical example to demonstrate that people in ancient India were cognizant of the significance of the corporeal things. However, none of their philosophies primarily focused on the centrality of things. Thing-oriented doctrines like thing theory and object-oriented ontology seek to solely highlight the primacy of material things in human life. Thing theory studies how material things shape and control human beings.

\section{REFERENCES}

Bogost, Ian. Alien Phenomenology, or What It's Like to Be a Thing. Minneapolis: University of Minnesota Press, 2012. Print.

Braddock, Alan C. "From Nature to Ecology: The Emergence of Ecocritical Art History". A Companion to American Art. Ed. John Davis, Jennifer A. Greenhill and Jason D. LaFountain. Chichester: John Wiley \& Sons, Inc., 2015. Print.

Britto, M. John. "An Ecocritical Reading of William Wordsworth's 'Tintern Abbey"'. Academic Research International. 2.1. (2012): 720-725. Web. 4 Feb. 2012. 
"Cārvāka". Chinese Buddhist Encyclopedia. $\quad$ Web. $14 \quad$ July 2016. <http://www.chinabuddhismencyclopedia.com/en/index.php/C\%C4\%81rv\%C4\%81ka>.

"Charvaka and Epicureanism: A Brief Comparative Essay". Web blog post. Historum. 28 Mar. 2014. Web. 15 July 2016. <http://historum.com/blogs/civfanatic/5457-charvaka-epicureanism-briefcomparative-essay.html $>$.

Copleston, Frederick. A History of Philosophy: Greece to Rome. Vol. 1. New York: Doubleday, 1993. Print.

Dasa, Satyanarayana. "Indian Schools of Philosophy and Theology". Jiva. Web. 14 July 2016. <http://www.jiva.org/indian-schools-of-philosophy-and-theology/>.

Dicker, Georges. Berkeley's Idealism: A Critical Examination. Oxford: Oxford University Press, 2011. Print.

Dwarakanat, M.R. "Purva Mimamsa Philosophy". Sringeri Vidya Bharati Foundation Inc, USA. Web. 12 July 2016. <http://svbf.org/newsletters/year-2014/purva-mimamsa-philosophy/>.

Gabriel, Markus. Fields of Sense: A New Realist Ontology. Edinburgh: Edinburgh University Press Ltd, 2015. Google Book Search. Web. 4 Feb. 2016.

Gratton, Peter, and Paul J. Ennis, eds. The Meillassoux Dictionary. Edinburgh: Edinburgh University Press Ltd., 2015. Google Book Search. Web. 4 Feb. 2016.

Gupta, Bina. An Introduction to Indian Philosophy. New York: Routledge, 2012. Google Book Search. Web. 27 July 2016.

Harman, Graham. The Quadruple Object. Winchester: Zero Books, 2011. Print.

Harryman, William. "Philosopher Graham Harman - Speculative Realism and the Philosophy of Tristan Garcia". Web blog post. Integral Options Cafe. 01 Feb. 2013. Web. 12 Feb. 2016.

Hiriyanna, M. The Essentials of Indian Philosophy. $1^{\text {st }}$ ed. Delhi: Motilal Banarsidass Publishers Private Limited, 1995. Print.

Marbaniang, Domenic. Epistemics of Divine Reality: What Knowledge Claims of God Involve. Google Book Search. 2011. Web. 27 June 2016.

"Maya (Illusion)". America Pink. Web. 28 June 2016. <http://america.pink/mayaillusion_2931407.html>.

Menon, Sangeetha. "Advaita Vedanta." Internet Encyclopedia of Philosophy: A Peer-Reviewed Academic Resource. Web. 28 June 2016. <http://www.iep.utm.edu/adv-veda/\#SH2b>.

Morton, Timothy. Realist Magic: Objects, Ontology, Causality. Ann Arbor: Open Humanities Press, 2013. Web. 18 April 2016.

"Purva Mimamsa". Indian Philosophy Simplified. Web. 12 July 2016. $<\mathrm{http} / / /$ indianphilosophy.50webs.com/purvmima.htm>.

"Realism". Britannica Ready Reference Encyclopedia. Vol. 8. New Delhi. Encyclopedia Britannica (India) Pvt. Ltd., 2004. Print.

"Samkhya". Indian Philosophy Simplified. Web. $27 \quad$ June 2016. <http://indianphilosophy.50webs.com/samkhya.htm >.

Sinha, Jadunath. Outlines of Indian Philosophy. $2^{\text {nd }}$ ed. Calcutta: New Central Book Agency (P) Ltd., 1985. Print.

Sturgess, Stephen. The Supreme Art and Science of Rajja Krya Yogā: the Ultimate Path to SelfRealization. London: Singing Dragon, 2015. Print.

"Vaisheshika Darshana". Hindu Online. Web. 12 July 2016. <http://hinduonline.co/Scriptures/VyesheshikaDarsana.html>. 